\title{
LA FIESTA DE LAS SIETE CRUCES DE TIXMÉHUAC
}

\section{María Jesús Cen Montuy}

Resumen: Este trabajo constituye un primer acercamiento a la fiesta de las Siete Cruces, que se realiza cada año los días dos y tres de mayo, en el municipio de Tixméhuac, ubicado al sur del estado de Yucatán. Está organizado básicamente a partir de dos momentos: en el primero se ofrece una descripción general de la fiesta, incluyendo los aspectos novedosos o recientes de dicha celebración. El segundo constituye una propuesta inicial de interpretación y explicación de los cambios en el financiamiento de las actividades, intentando responder a dos preguntas: ¿por qué el modelo organizativo de financiamiento para la fiesta de las Siete Cruces se ha abandonado? y ¿por qué ese financiamiento se volvió individual?

Palabras clave: Fiestas tradicionales, cruces, vaquería, financiamiento, Sociedad de Hermanos de las Siete Cruces.

Abstract: This work constitutes the first approach to the Fiesta de las Siete Cruces, which takes place every year on the second and third of May, in the municipality of Tixméhuac, located to the south of the state of Yucatan.It is organized basically from two moments: in the first one a general description of the Fiesta is offered, including the novel or recent aspects of the above mentioned celebration.The second one constitutes an initial proposal of interpretation and explanation of the changes in the financing of the activities, trying to answer two questions: why has the organizational model of financing for the Fiesta de las Siete Cruces given in? and, why did this financing become individual?

Keywords: Traditional parties, crouces, vaqueria, financing, Sociedad de Hermanos de las Siete Cruces.

Recepción: 14 de noviembre de 2007

Aceptación: 24 de marzo de 2008 



\title{
LA FIESTA DE LAS SIETE CRUCES DE TIXMÉHUAC
}

\author{
María Jesús Cen Montuy \\ Centro InAH-Yucatán
}

\section{Introducción}

Pleno de festividades y conmemoraciones, el calendario católico integra un complejo ciclo de celebraciones populares - unas más largas o de mayor fama que otras- con diverso grado de solemnidad, recogimiento y devoción.

En esta agenda ritual, uno de los días más importantes en México es, sin duda, el 3 de mayo, dedicado a la Santa Cruz. De ahí que no resulte extraño que en su Calendario de fiestas populares, Imelda de León (1988:251-253), consigne para nuestro país, más de 170 lugares donde se efectúan ceremonias en esta fecha. El número en realidad, debería ser bastante mayor espacialmente si consideramos que dadas sus características, muchas de estas celebraciones (más íntimas o sencillas), no están registradas.

Sin entrar en mayor detalle - hay numerosos y muy completos estudios efectuados en distintas regiones del país-, podemos afirmar que en la actualidad estos festejos conjugan las creencias de los pueblos indígenas, de profundas raíces prehispánicas, con el culto y los dogmas importados por los conquistadores. Como en otros muchos casos de nuestro continente, en Yucatán, con la llegada de los españoles, las ceremonias nativas se transformaron en complejas muestras de devoción dirigida —al menos en apariencia — hacia las imágenes católicas, resignificadas ahora para integrarlas a la propia realidad del pasado y del presente.

Así, estas fiestas llamadas tradicionales, estos "rituales colectivos, a la vez privados y públicos, que conmemoran hechos significativos, principalmente religiosos" (Barabas y Bartolomé, 2003:54), pueden ser sinónimo de celebración, regocijo, alegría y gozo y resultan, sin duda, parte fundamental de la vida de los pueblos indígenas. Son también razón para romper la rutina de lo cotidiano: condensan en sí mismas un intrincado tejido de elementos que incluyen, por ejemplo, la danza, la música, los cantos y los rezos.

De maneras diferentes y en niveles muy distintos, dichas actividades ponen de manifiesto la comunicación del ser humano con un ser que concibe como superior. La fiesta es la convivencia de lo divino y lo terrenal, lo sagrado y lo profano, y es a partir de la celebración que se establecen distintos canales de enlace con la(s) deidad(es) para hacer alguna petición, agradecer el socorro y la gracia 
recibidos o tal vez simplemente para recordarle al santo patrono la fidelidad de uno de sus hijos.

Para el caso de Yucatán, podemos decir que con el transcurso del tiempo, las celebraciones patronales han ido transformándose al reemplazar gremios por cofradías y modificar la estructura que las conformó en sus inicios bajo el sistema de fiestas, más que de cargos. ${ }^{1}$ Así, en la actualidad hay una considerable diversidad de estos festejos en las distintas comunidades del estado. En efecto, el complejo ritual constituye aquí un intrincado sistema en el cual con frecuencia participan integrantes de distintos estratos sociales, integrando una enorme riqueza de elementos culturales "regionales" e indígenas. De muchas maneras, el tiempo de la fiesta — sagrado, al fin— no sólo permite sino que incita el empleo de elementos mayas y mestizos, antiquísimos algunos, otros bastante novedosos, revitalizándolos con cada nuevo ciclo.

El trabajo que ahora presento ${ }^{2}$ constituye un primer acercamiento a la fiesta de las Siete Cruces, que se realiza cada año los días 2 y 3 de mayo, en el municipio de Tixméhuac, ubicado al sur del estado de Yucatán. Está organizado básicamente a partir de los dos grandes momentos que sigue dicha celebración: en el primero se ofrece una descripción general de las actividades, incluyendo los aspectos novedosos o recientes de los festejos. El segundo constituye una propuesta inicial de explicación de los cambios en el financiamiento de las actividades, intentando responder a dos preguntas: ¿por qué el antiguo modelo organizativo de financiamiento colectivo para la fiesta de las Siete Cruces se ha abandonado? Y ¿por qué ese financiamiento se volvió individual?

\section{Las cruces en Yucatán}

De profundo significado cosmológico, la cruz es el eje de la vida y el universo maya. Ya Rafael Girard (1966: 85-91) demostró ${ }^{3}$ hace medio siglo que el "Árbol de la cruz" o "Cruz foliada", que se encuentra en uno de los tableros de Palenque, es una representación de la ceiba, que es también considerada el árbol primigenio, sagrado y padre-madre de toda vida. En esta imagen en particular también se han podido identificar algunos rasgos de las plantas de maíz, por lo cual el

\footnotetext{
${ }^{1}$ Para el sistema de cargos en la Península véase Quintal, 2003a.

${ }^{2}$ El material de campo que analizaré en este trabajo proviene de la observación de las fiestas de mayo de 2006 y 2007, en Tixméhuac, Yucatán, como parte del proyecto Etnografía de los mayas de la Península de Yucatán, del Instituto Nacional de Antropología e Historia-Yucatán, que a su vez forma parte del proyecto Etnografía de las regiones indígenas de México en el nuevo milenio, de carácter nacional, también a cargo del INAH.

${ }^{3}$ En su texto "Profetismo, milenarismo y mesianismo en las insurrecciones mayas de Yucatán", Barabas advierte "que estas concepciones pueden hacerse extensivas a los mayas de Yucatán en la medida que forman parte de la cultura maya prehispánica, relativamente homogénea en sus manifestaciones regionales" (1974: 609).
} 
motivo cruciforme maya también se ha vinculado con dicho cereal, básico en la alimentación y la cultura de dicho pueblo.

Este símbolo también representa el axis mundi, vaso comunicante entre los mundos terrestre y celeste (Tozzer, 1907: 154), y figura central de una suerte de "paraíso" maya, en el cual los hombres gozarían de abundancia, de bienestar y de descanso bajo la sombra de una enorme ceiba. Barabas, por su parte, señala que, "aunque se considera que este Árbol cruciforme había surgido a raíz del sacrificio del Alto Dios; las cruces a las que se rindió culto posteriormente, no eran simples representaciones de estos conceptos, sino entes sagrados (hierofanías) en sí mismos, potentes y por lo tanto eficaces" (Barabas, op. cit.: 610). Por lo tanto —según esta autora-, la cruz prehispánica representa al árbol que dio origen a la vida.

Al hablar del culto a la Cruz Parlante — por ejemplo— se puede señalar de una prevalencia de la propia potencialidad individual, al mismo tiempo que entenderla unida a la de Jesucristo, de quien era parte y vehículo. En la cultura maya, la existencia de ídolos parlantes es bien conocida, éstos funcionaban a manera de oráculo acerca de lo que habría de acontecer a los hombres (Ibid.: 611).

En efecto, los mayas macehuales ${ }^{4}$ del centro de Quintana Roo tuvieron un culto mesiánico a la Cruz Parlante. Aparecida en 1850, tres años después de iniciada la Guerra de Castas, dicha cruz prometía a los macehuales o cruzoob inmunidad ante los ataques de sus enemigos, así como la instauración de una nueva sociedad maya, donde no existiría el hambre, la injusticia, el sufrimiento y la esclavitud. Hoy, con el tiempo de por medio, en Quintana Roo se reconoce la existencia de los santuarios de Chumpón, Chan Cah Veracruz, X-Cacal Guardia y Tulum. Sobre el tema, Rejón comenta:

La religión popular del pueblo maya tiene múltiples significados, prueba de un sincretismo religioso entre la cultura propia y la hispana. Los mayas adaptaron el catolicismo español a su propia visión del mundo con una gran capacidad para absorber y sintetizar nuevas ideas sin destruir las estructuras básicas de su modelo del cosmos (Rejón, 2001: 33).

La misma investigadora señala que autores como Evon Vogt y David Freidel subrayan que:

Tal vez el ejemplo más impresionante de esta clase de transformación sea la adaptación maya de la cruz cristiana al símbolo que representa el Árbol del Centro del Mundo o Yaxche'il kab como lo llamaban los mayas de la Conquista, el cual atraviesa los tres planos del universo (cielo, tierra e inframundo). Es posible que esta transformación explique el gran fervor cristiano que los actuales mayas despliegan ante sus cruces de madera (Ibid.: 34).

\footnotetext{
${ }^{4}$ Los macehuales son los mayas que habitan el estado de Quintana Roo, diseminados en el área central de dicho estado.
} 
A partir de este contexto, entendemos por qué la cruz es un símbolo importante para los mayas peninsulares, especialmente para los que habitan el centro de Quintana Roo. Rejón apunta:

[...] por lo general, las cruces son hechas de madera de cedro o caoba por el propio interesado y existe la creencia de ser más milagrosas las que se hacen en Viernes Santo por ancianos de más experiencia en inclinación religiosa. No todas las cruces son igualmente poderosas ni desempeñan la misma función; existe entre ellas una especie de jerarquía. Las cruces patronales de menor rango y poder son las que tienen por objeto la protección del grupo doméstico. Sucede en ocasiones que alguna de estas cruces resulta muy milagrosa por lo que se vuelve objeto de especial veneración por parte del grupo familiar, se le construye su nicho especial y se le dedica una fiesta particular (Ibid.: 34).

En Yucatán, algunas de las apariciones de cruces están relacionadas con los cenotes, los rayos y los árboles. Por ejemplo, la cruz de Chuchub, en la ranchería del mismo nombre, ubicada en el municipio de Tixméhuac, se apareció sobre un cenote. Según la historia, los habitantes de dicha ranchería descubrieron un árbol en forma de cruz sobre el cenote del lugar, de modo que se dieron a la tarea de cortar las ramas del árbol hasta "que la cruz ya no estaba tapada con las hojas del árbol y se veía muy bien que era una cruz. Está hecha de una sola pieza de madera y es de color verde". Los habitantes del lugar llevaron la enorme cruz a la iglesia de Tixméhuac y hace aproximadamente 50 años, dejaron de festejarla el 3 de mayo, pues según datos de nuestras entrevistas, la gente prefería irse a la fiesta del vecino pueblo de Chumayel, que ocurre en esas mismas fechas.

Otro ejemplo de cruces milagrosas lo encontramos en el sur de Yucatán, en el municipio de Chacsinkín, pueblo vecino de Tixméhuac donde se dice existe una que camina, y según los pobladores esta cruz se encuentra en la iglesia del pueblo. Cuentan que si la persona que la toca tiene fe, ésta caminará. No tengo, por ahora, más datos respecto de este caso en particular; sin embargo, puedo señalar otras referencias, como lo que se cuenta de la de Popox, originaria del rancho del mismo nombre en el pueblo de Hocabá. Esta cruz recorre varios pueblos a lo largo del año, permaneciendo nueve días en cada uno. Se le considera milagrosa y sus devotos llegan a ofrecerle hasta alhajas de oro a cambio de sus milagros. Está custodiada por un grupo de personas llamados "Los Hermanos de la Santa Cruz de Popox". Por otro lado, en Ek' Balam, municipio de Temozón, se festejaba hasta hace una década a la Santa Cruz Tres Reyes, y en el municipio de Valladolid en Xocén, se rinde devoción especial a una cruz parlante.

En el caso de las Siete Cruces de Tixméhuac, una de ellas fue descubierta por un milpero: cuando se dirigía a su terreno, vio caer un rayo en un árbol y al acercarse descubrió la milagrosa formación. La historia da para más, y volveré sobre ella más adelante, pero antes de continuar, he de insistir en el asunto de que en Yucatán las cruces no sólo fueron - y son-motivo de veneración por sus apariciones. A ellas también se les adjudican algunas funciones muy particulares. 
Desde la época colonial se solía colocar una cruz de madera, llamadas a veces "de b'aalam", en cada uno de los cuatro puntos cardinales o sobre los caminos y entradas a la población, señalando los límites de la comunidad. El nombre que aquí señalo puede venir de la idea de que son entidades protectoras: según la tradición oral local, en cada una de ellas estaría apostado un ser sobrenatural, imaginado con forma de jaguar. En cualquier caso, las cruces, generalmente aseguradas encima de un pequeño montón de piedras, se supone que están hechas de madera de xuul, que significa "fin". Indican, así, el confín del pueblo.

Tal parece que, hoy día, existe la creencia de que según el número de caminos que unen un asentamiento con otras comunidades o lo comunican con el monte, es el número de b'aalamo'ob que corresponde a cada lugar (Quintal et al., 2003a: 319-320). Se ha señalado que en la región oriental del estado, en la zona de cenotes, cada pueblo solía reproducir en su traza la imagen del mundo. Es decir, en el centro debía haber una gran fuente subterránea de agua y una enorme ceiba, cuyas raíces - en ocasiones - surgían del propio cenote y hacia los cabos del pueblo se debían localizar cuatro cruces b'aalam (en el centro de los lados del mundo, es decir, en los intercardinales). Entre el cenote-ceiba y cada una de las cruces, los grupos familiares ocupaban su respectivo solar. Asimismo, se señala que en el oriente y sur del Estado, las cruces son los santos más venerados por la población mayahablante. Precisamente las que se veneran en el oriente, suelen ser cruces verdes, de fuerte simbolismo indígena: son cada una, un Ya 'axche', el primer árbol, el axis mundi maya, el eje del mundo (Ibid.: 351-352). Se podría decir que en el sur del Estado sucede lo mismo. Como detallaré más adelante, las Siete Cruces de Tixméhuac son también verdes, pero antes, me referiré un poco más al contexto de nuestro caso.

\section{Datos generales sobre Tixméhuac}

He dicho ya que el municipio se localiza al sur de Yucatán, y que su nombre proviene de la voz maya $x$-ne'ac, "cola de la tortuga". La división política comprende la cabecera municipal y comisarías: Sabacché, Kimbilá, Sisbic, Dzutoh, Chicán y Chuchub. Su territorio abarca una superficie total de $251.65 \mathrm{~km}^{2}$ (Diagnóstico Municipal, 2005: 6).

Según los resultados del II Conteo de Población y Vivienda 2005 del INEGI, el municipio cuenta con un total de 4329 habitantes, siendo 3116 de ellos mayores de cinco años de edad y hablantes de lengua maya. La población que se adscribe al catolicismo abarca un total de 2260 personas $^{5}$ y los no-católicos (ubicados en este mismo rango de edad) son, en total, 1237 individuos.

Como en la región, en Tixméhuac la vida depende en gran medida de las actividades vinculadas con el campo, la mayor parte de la población económicamente

\footnotetext{
${ }^{5}$ Considerando personas de cinco años o más.
} 
activa está dedicada a la siembra de maíz de temporal, mediante la aplicación del sistema tradicional de roza, tumba y quema, si bien también es posible encontrar algunos cultivos asociados, intercalados o campos de monocultivo (frijol, calabaza, ibes). Se cultiva también sandía y chile habanero, mediante riego manual. En efecto, $55.46 \%$ de la PEA se dedica al sector primario (producción de materia prima o alimentos). El fruto de dicha actividad se utiliza principalmente para el autoconsumo, poniendo el excedente a la venta (Diagnóstico Municipal, 2005: 10).

Por otro lado, la ganadería no es una actividad que represente mayor impacto en el municipio, ya que se practica a pequeña escala, siendo la mayoría de los propietarios particulares que cuentan apenas con algunas cabezas de ganado, generalmente del llamado "de poste" o traspatio. A ese nivel también se crían cerdos, gallinas, patos, conejos, pavos y uno que otro borrego. En cuanto a la producción artesanal, quizás los aspectos más relevantes sean el urdido de hamacas y el bordado. La actividad económica se complementa con el comercio y los servicios, contando Tixméhuac con tiendas de abarrotes, loncherías, panaderías, cantinas, mercerías y zapaterías, entre otros establecimientos. Eso sí, los comerciantes formales obtienen la mercancía del exterior (Diagnóstico Municipal, 2005: 11).

Asimismo, la localidad cuenta con del Sistema de Educación Pública y templos de diversa adscripción, así como servicios de taxi y autobús, electricidad, agua potable, radio, registro civil, biblioteca y parques.

Tixméhuac está considerado como un municipio de alto grado de marginación, con un índice de 0.94545; ocupa el noveno lugar en el contexto nacional y estatal por municipio. ${ }^{6}$ El poder adquisitivo de esta comunidad es muy bajo, su economía no está desarrollada, carecen de proyectos y actividades generadoras de riqueza por lo que la actividad comercial y económica es poca.

Con una idea breve, pero más o menos general de la comunidad, repasaré ahora algunos datos sobre el origen de las llamadas Siete Cruces, para continuar con una descripción particular de las actividades realizadas en dicha fiesta y, finalmente, presentar algunas reflexiones al respecto.

\section{La historia de las Siete Cruces}

No existe en la comunidad ningún registro escrito sobre la historia de las Siete Cruces. Algunos de los pobladores entrevistados comentan que el festejo a estos "santos", como también se les llama, tiene aproximadamente 100 años de antiguiedad. En realidad, se puede decir que durante el trabajo de campo obtuve solamente dos versiones sobre el origen y la fiesta de estas cruces.

La primera versión advierte que hace muchos años vivió en Tixméhuac un matrimonio que nunca pudo tener hijos. La señora, de nombre Juana Bautista, y

${ }^{6}$ XII Censo General de Población y Vivienda 2000, INEGI. 
su marido "creían mucho en la Santa Cruz, siempre le rezaban, le tenían mucha creencia y fe".

En una ocasión, camino a su milpa, el hombre vio un relámpago y enseguida encontró una cruz. Al llegar a su casa le contó lo ocurrido a su mujer, quien lo acompañó hasta el lugar donde había ocurrido este evento maravilloso, limpiaron juntos el lugar y "cortaron las hojas porque estaba en un árbol y la sacaron del árbol y se la llevaron a su casa y así entonces ya tuvieron entonces dos cruces, la que ya tenían en su casa y la que se apareció".

A pesar del carácter milagroso de lo ocurrido doña Juana pensó en rezarle, como era su costumbre, tan sólo el tres de mayo, pero la gente del pueblo al enterarse del prodigio le pidieron que rezara la novena completa. El compromiso, según la señora, "era mucho" para ella sola, de modo que algunas de las personas se ofrecieron a colaborar con la novena, ${ }^{7}$ rezando cada una de ellas una noche. En total se ofrecieron ocho nocheros más.

La informante no recordó quién había propuesto buscar otra cruz para reunir — tal como manda la tradición - un grupo de tres. Una vez hallada la tercera, se tallaron tres cruces más, pequeñas. De hecho, nos advirtieron, cada uno de los "santos", debe tener su réplica en menor tamaño que "son sus hermanas". Ya con los "duplicados", las cruces fueron vestidas. ${ }^{8}$

Una noche, doña Juana soñó que

[...] le preguntaron que en donde estaba la otra cruz y que contestó que sólo había seis cruces y que en su sueño le dijeron que tenía que buscarla, así [que] cuando despertó la señora pues se lo contó a su marido y empezaron a buscar la otra cruz, y la encontraron, pero no recuerdo muy bien cómo es que juntaron todas las siete cruces grandes y las chicas, pero se juntaron las siete cruces y entonces empezaron a rezarle, así empezó la fiesta, sólo con las novenas. ${ }^{9}$

${ }^{7}$ Sobre novenas véase Quintal, 2003a.

${ }^{8} \mathrm{~A}$ las cruces se les viste con una tira bordada que asemeja un "huipil".

${ }^{9}$ Quintal et al. (2003: 334) mencionan que: "en muchas casas de familias mayas es frecuente encontrar cruces o santos familiares, heredados a veces de los antepasados o adquiridos en cualquier momento de la historia de la familia. Los miembros del grupo familiar suelen rendir culto a estas imágenes por medio de una institución llamada novena. Consiste ésta en un grupo de parientes y vecinos de la familia en cuestión que se organizan para rezar durante nueve días seguidos, cada noche, un rosario. La celebración del culto está en manos de un grupo de parientes que residen en casas contiguas o cercanas. Conforme crece la devoción al santo, su novena también se vuelve más importante; se agregan otros parientes y vecinos llegando incluso, en algunos casos, a constituirse en celebración de un barrio o del sector del pueblo". Un ejemplo de esto es lo que ocurre en la población de Yaxunah en donde, "las diferentes familias católicas organizan actividades rituales calendarizadas en honor a las Santas Cruces pertenecientes a diferentes grupos de familias. Esto les permite mantener la cohesión e identidad familiar y católica frente a los evangélicos. Una de estas 'sociedades' está formada por 13 personas; la Cruz de los Canul integra a diez familias emparentadas y la Santa Cruz de los Chuc, la principal familia de católicos, agrupa a cerca de 15 familias de la 'colonia de los Chukes', que es el 'rumbo donde vive el santo'.

Otro ejemplo es la celebración de la Santa Cruz en el pueblo de Chaksinkín (pueblo vecino de Tixméhuac ), en donde "la fiesta $[. .$.$] con su respectiva novena, puede incorporar a segmentos ma-$ 
Estas siete cruces (que en realidad son 14) son verdes. La más pequeña mide $1.40 \mathrm{~m}$ y la más grande 1.70. Las mayores llevan dibujos alusivos a la pasión de Cristo (los dados con los que los soldados se jugaron las vestiduras, la lanza que le atravesó el costado, el gallo que cantó cuando lo negó Pedro, el martillo y los clavos, la manta con la cual la Verónica le enjugó el rostro, etcétera). Las pequeñas también son verdes, sólo que no llevan ningún dibujo y miden entre 20 y $50 \mathrm{~cm}$ de altura. Hasta ahora no hemos podido saber de qué madera están hechas ni quién las pintó (fotografía 1).

En una ocasión, la dueña de las cruces enfermó y mandó buscar a todos "los nocheros", ${ }^{10}$ a quienes pidió que a su muerte se encargaran del cuidado de aquéllas. Tras su fallecimiento y el de su esposo, los nocheros tomaron la decisión de llevarse las cruces y dejarlas en casa de alguno de ellos. Asimismo, convocaron a más personas interesadas en formar una sociedad de "Hermanos", que estaría a cargo de la organización de los festejos a los santos, y no simplemente de los rezos de la novena. Así fue como se integró el grupo "Los Hermanos de las Siete Cruces”. Posteriormente elegirían a un Hermano Mayor, responsable de dirigir sus actividades. Se acordó también ofrecer siete cabezas de cochino ${ }^{11}$ y siete ramadas — canastillas de bejuco adornadas con panes, frutas, elotes y panales, con todo y sus respectivas abejas- , una para cada cruz, y hacer una vaquería ${ }^{12}$ en su honor.

yores de una comunidad o sólo a algún 'sector' de la comunidad, como en Chaksinkín donde hace cerca de 50 años cada mitad del pueblo celebraba alternadamente año con año a las cruces ubicadas respectivamente a la salida hacia Tixméhuac al oeste del poblado, y a la salida a Peto, en el este. Cada una contaba con un comité de 'interesados' con su directiva, en la que estaban representados las principales parentelas de una u otra banda del pueblo". Para mayor información veáse Quintal et al. (2003a).

${ }^{10}$ Los nocheros son los "encargados" de cada una de las noches en las que se reza un rosario en honor a las cruces, en este caso.

${ }^{11}$ A esta danza se le conoce generalmente con el nombre de Pool k'ek'en (pool significa "cabeza" y kekén "cerdo"). Luis Pérez Sabido la describe de la siguiente forma "De la casa del jefe de los organizadores sacaban en procesión la cabeza de cerdo para llevarla a la casa principal como cortesía de los amos (para esto) colocaban en una mesa pequeña, bien limpia, una cabeza de cerdo en barbacoa, en una jaula arqueada, tejida de madera y adornada con papeles multicolores y cintas angostas, poniéndole además a los lados: panes de harina, rollos de cigarrillos de joloch, mazorcas sancochadas y en pibil, medias botellas de anís; monedas de plata en los ojos (del cerdo) y en la boca un buen trozo de pan blanco conocido generalmente en Yucatán como "francés". La mesita la adornaban de igual manera que el arco de la jaula; en los laterales y al frente prendían largas cintas que asían las bailadoras en traje de vaqueras (es decir, con sombrero y banda), puesto que tenían que bailar (bajo el sol) cuando la llevaran al salón donde la homenajeaban a todo ritual. A las doce en punto la ceremonia de salida se iniciaba. Un indígena cargaba la cabeza de cochino en su cabeza y las cintas eran asidas por las "vaqueras"; se anunciaba la salida con cohetes y la orquesta tocaba una alegre jarana especial (pascalle) que todos bailaban". (1983: 134,136).

12 "La vaquería, $[. .$.$] nació en la haciendas. Después de la marca del ganado, las mujeres —vaque-$ ras- atendían solícitamente a los invitados, y a sus esposas y como final de fiesta danzaban viejos sones mayas influidos por la música española o viceversa. Las letras ajustadas a la música, olían a picardía, a pesar de la censura que, desde el Oidor López y otras disposiciones posteriores, se impuso a los cantos y danzas indígenas (Irigoyen Rosado, 1973: 36 citado en Quintal, 1993: 22). La música 


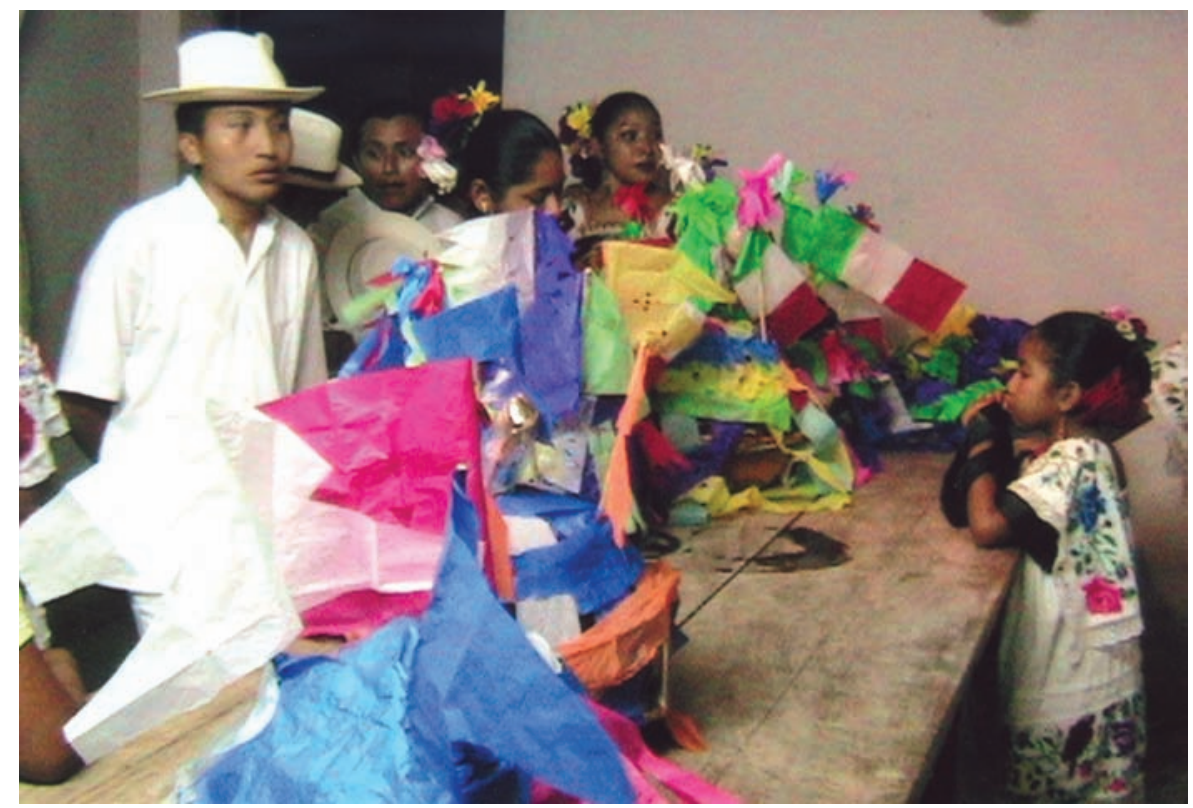

Foto 1.

Cada una de las imágenes permanecería durante un año en la casa de alguno de los hermanos, siendo el anfitrión el responsable de festejarla. A fin de colaborar con tan "onerosa distinción", los Hermanos aportarían una cuota mensual, reuniendo así el dinero que serviría para apoyar al responsable en turno, en la compra de ollas, mesas, manteles, sillas y todo lo necesario para la fiesta. ${ }^{13}$ Con el tiempo la fiesta fue creciendo y cambiando, el grupo de Hermanos llegó a reunir a 80 agremiados — hombres y mujeres-, y la lista de personas que esperaban tener las Cruces era muy larga. Solamente los Hermanos podrían recibirlas.

En una ocasión, una de las hermanas — quien tenía las cruces en su casasoñó que justamente donde ellas estaban, había siete señoritas, cada una con su maleta. Las jóvenes le dijeron que se iban de la casa porque no podían dormir en el mismo sitio donde ella y su esposo. Cuando despertó, decidió mandar construir un cuarto cerca de su sala sólo para las cruces. Se dice que, a partir de ese suceso, todo aquel Hermano que recibiera a las cruces debería conservarlas en un lugar especial para ellas, colocarlas en altar cubierto con manteles blancos y adornar dicho altar con flores.

que se baila en las vaquerías es la jarana, baile típico de la península de Yucatán. La vaquería se lleva a cabo, casi siempre, en "los salones" (corredor) del palacio municipal o de la comisaría y suele dar inicio ya bastante avanzada la noche (Quintal, 1993: 23).

${ }^{13}$ Todos estos enseres se compran una sola vez y se dan en préstamo a quien los solicite. 
La segunda versión sobre el origen de las Siete Cruces es mucho más corta:

[...] mi tío me contó hace muchos años —él todavía estaba vivo y no era muy viejo-, pues entonces me dijo que esas cruces eran siete porque Tixméhuac tiene siete rancherías y sus salidas, o sea sus cabos del pueblo son siete y que entonces esas cruces eran las que estaban en los cabos del pueblo, pues que las juntaron y por eso son siete. Luego, que les empezaron a rezar y luego, pues, les hicieron su fiesta. Que antes era sólo su rezos de las novenas, y pues ahora hay su vaquería. Eso me lo contó mi tío, pero nada más eso sé de las cruces, porque aquí en el pueblo nadie lo sabe su historia.

El entrevistado aseguró no saber quién comenzó a celebrar la fiesta y cómo se formó la agrupación de los Hermanos. También mencionó que no conocía la primera versión sobre el origen de éstas. Sin embargo, se refirió a una versión más, que ubicaría el surgimiento — por decirlo de alguna manera- de las cruces en 1800 , siendo un total de 14 (siete mayores y siete pequeñas). Aquí entra nuevamente la explicación onírica que representa a las siete cruces como siete jóvenes: en una ocasión la dueña de la casa se bañó en el mismo cuarto donde estaban las cruces y, por la noche, soñó con siete chicas de pie junto a su mesa, cada una con su maleta, advirtiéndole que debían ir a buscar otro sitio para vivir, pues como eran "señoritas" no podían vivir en el mismo lugar donde duerme un matrimonio. Así, la señora despertó recordando su sueño y mandó construir un cuarto especial para las cruces, que es donde se encuentran hasta ahora. ${ }^{14}$

Queda un detalle más por mencionar: por causas que ahora la gente ignora, a las cruces se les cuelgan muñecas. En efecto, nadie sabe por qué, pero es de sobra conocido el hecho de que:

Desde siempre les cuelgan sus muñequitas a los santos, antes eran de trapo, pero ahora son de plástico [...] son esas barbis de plástico que venden ahora, porque ya no hacen muñecas de trapo, ahora todo es de plástico. Entonces tú le pides al santo por tu salud, o por tu trabajo, así que te cure de alguna enfermedad y le ofreces una muñeca, entonces lo pides y en el próximo año le pones su muñeca, se llama cambio de salud, pero también si te gusta una muñeca pues se la pides a los santos y la agarras y el próximo año le devuelves dos muñecas, si no lo devuelves te enfermas y te puedes morir.

En realidad ninguno de mis informantes pudo explicar el origen de esta peculiar devoción, sólo indicaron que era parte de la costumbre. No obstante, todos parecían conocer bien la adaptación local del sistema de k'eex, o “cambio”.

\footnotetext{
${ }^{14}$ Rejón (2001:33) reporta unas cruces que sangran en la comunidad de Oncan, municipio de Mérida. La gente del pueblo menciona que "estas cruces tienen vida, están pidiendo su casita, ya que no quieren que otros duerman con ellas. La familia que tiene las cruces menciona que las cruces están pidiendo un nicho fuera de la casa donde puedan ser puestas y veneradas por todas las personas del pueblo". Para mayor información consultar Lourdes Rejón Patrón (2001).
} 
Durante las primeras celebraciones de las Siete Cruces no había música y baile, solamente se tocaban tres tunkules ${ }^{15}$ para avisar que los "rezos" estaban por comenzar, uno de esos instrumentos tiene grabado el año 1816; sin embargo, una de las entrevistadas comentó que existió un tunkul más antiguo fechado en el año 1700 "y tantos", desafortunadamente ese tunkul se perdió y fue reemplazado por otro nuevo. Hay quienes advierten que además de estos instrumentos se utilizaban también flautas y violines para llamar a la gente a rezar.

Como señalé, este grupo de Hermanos responsables de las Siete Cruces fue creciendo en número hasta llegar a 80 aproximadamente, reuniéndose cada mes. Se acordó la entrega de una pequeña cuota mensual y, entre todos, se eligió a un Hermano Mayor, encargado de dirigir las reuniones mensuales y de administrar el dinero. Este grupo llegó a varios acuerdos sobre el festejo de las Siete Cruces, uno de los Hermanos propuso que se bailara "La cabeza de cochino", escogiendo a siete Hermanos, cada uno de los cuales ofrecería una cabeza de cochino a las Cruces. Adicional a esto,

[...] antes había como un teatro con la cabeza de cochino, pero ya no lo hacen, dice mi abuela que los hombres se vestían de mujeres, así de mestizas y tenían sus sonajas, las hacían con jícaras, le ponían maíz y luego las envolvían y eran sus sonajas. Hoy si hacen esas sonajas, las cabezas pero son los del grupo de baile de jarana los que bailan. Hasta sus coplas decían, ahora nada, quien sabe porqué [...]

Por si fuera poco, después de elegir a los siete Hermanos para las cabezas, se seleccionaban otros siete para que cada uno de ellos ofrendara una ramada por cada cruz. Éstas eran una especie de jaulas hechas de bejuco, la gente les colgaba hileras de panes, flores, panales con todo y abejas. Al final de la celebración, cada uno de los hermanos tomaba una ramada o una cabeza de cochino y se los llevaba a casa (fotografía 2).

Antes de seguir adelante, es necesario que haga algunas precisiones sobre las cruces y su fiesta, que inicia con las novenas que se efectúan del 24 de abril al 2 de mayo. El día 3 no hay rezo. Estos rezos congregan especialmente a mujeres y niños de la comunidad, quienes ofrecen sus oraciones a la cruz, siempre en español. Algunos de los asistentes llevan veladoras y flores para ofrecerle a las cruces. Al término del rezo se reparte horchata o algún pan o dulce.

Como había señalado ya, los santos se encuentran en una habitación contigua a la casa, o bien en una casa desocupada. Se colocan en tres mesas a modo de altar, cada una cubierta por un mantel blanco, obsequio a las cruces. Junto a estas últimas se ubican varios floreros con flores artificiales, aunque en ocasiones la gente del pueblo les lleva flores naturales. Frente a las mesas se coloca una barra de madera que sostiene las veladoras y las velas que se encienden en cada rezo.

En frente del altar se colocan varias sillas de madera que sirven para que la gente que acude a rezar pueda sentarse. De acuerdo con el tamaño de la habi-

15 “Tambor horizontal hecho de un tronco ahuecado" (Diccionario Maya Popular, 2004). 


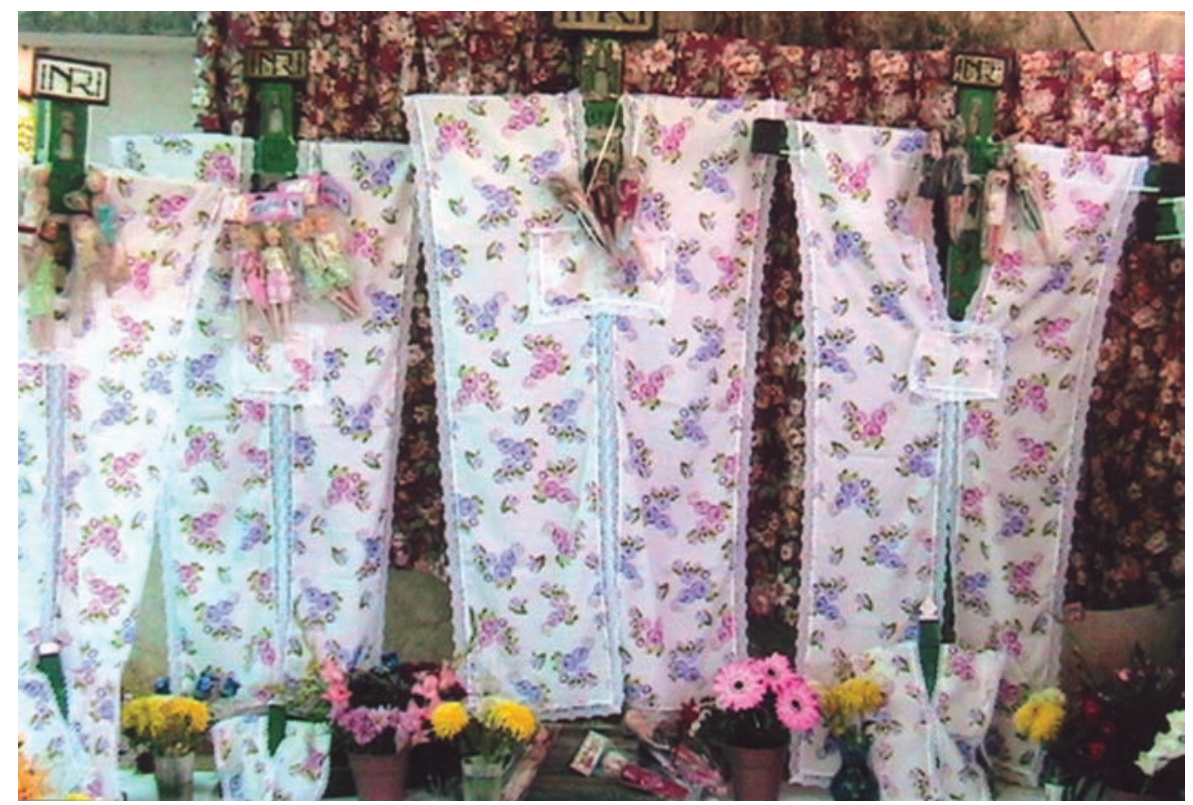

Fotografía 2.

tación es como se distribuyen las cruces y parece ser que la orientación no es importante. Cada una de las cruces tiene un sudario. Generalmente estos son obsequios de las familias o personas devotas y llevan bordados el nombre y la fecha de quien hizo el regalo. Estos sudarios están confeccionados con telas floreadas o bien, son blancos y llevan bordadas flores de colores, como si fuera un "hipil". Esto dependerá del gusto de la persona que haga el regalo.

El Hermano que tuviera las cruces era el encargado de preparar el chilmole que se comería el día 3; los Hermanos le entregaban una cantidad de dinero para ayudar con los gastos. También compraron ollas, cucharas, sillas y las mesas donde se asentaban las cruces. Todos estos objetos eran "propiedad de las cruces", quien recibe las cruces también recibe estos objetos.

\section{La fiesta hoy}

Entre el cambio y la pervivencia, la fiesta está llena de elementos que se encaminan a lograr la comunicación con lo sagrado. Se verá, entonces, cómo es la que se ofrece a las Siete Cruces y los cambios observados entre 2006 y 2007:

[...] ha cambiado mucho, porque ahora hay mas cosas que antes, pero también hay otras cosas que ya no se están haciendo porque los Hermanos ya no participan en la fiesta como antes, o sea que ya no apoyan al hermano que tiene las cruces y pues es más duro hacer la fiesta porque cuesta mucho dinero y la situación está muy mal. 
Durante los meses previos a las celebraciones, el Hermano responsable debe comenzar los preparativos. Entre sus deberes está el buscar y contratar el grupo musical y el de jaraneros ${ }^{16}$ — de Tixméhuac — que amenizará la fiesta de mayo. Debe, también: comprar o engordar al cerdo cuya carne servirá para la comida de los dos días de celebración y también buscar a la rezadora, comprar voladores (cohetes), flores, preparar el tinglado de madera con techo de palma, dentro se bailará la vaquería; buscar entre los Hermanos, a 13 de ellos que se ofrezcan para hacer las siete ramadas y cocinar las seis cabezas de cochino - la séptima está a cargo de quien guarda las cruces ese año-y, finalmente, encontrar a los nocheros para las novenas que comienzan el 24 de abril y concluyen el 2 de mayo.

En 2006, la familia responsable cumplió a cabalidad con el precepto de construir un tinglado para la vaquería, pero al año siguiente, los nuevos encargados decidieron que no era necesario y se optó por pedir permiso a la Presidencia Municipal para llevar a cabo el baile y la vaquería en los bajos del palacio, argumentando que si llovía la gente estaría resguardada, amén que se podía ahorrar un buen dinero.

Por costumbre, durante la madrugada del 2 de mayo se da muerte al cerdo que servirá de alimento esos dos días. Se prepara chicharrón y morcilla para comer ese mismo día. También se preparan las siete ramadas, que son llevadas a la casa donde se encuentran las cruces y se cuelgan del techo. Al mediodía, se sirve la comida a los santos: el plato que se ofrece a cada cruz consiste en chicharrón, tortillas y refrescos. Por la tarde, una mujer de la casa cambia "su ropa de los santos", una especie de sudario que puede ser de tela blanca, bordada con flores de colores o bien, de tela estampada. Éstos son obsequios de la gente de Tixméhuac.

Hasta 2006, las ramadas se hicieron sin tropiezo. Ese año, sin embargo, no se armaron porque ninguno de los Hermanos se ofreció a hacerlas. El que era responsable de las cruces, junto con su esposa, explicó que en aquella ocasión no recibieron la ayuda acostumbrada por parte de la agrupación, porque con el tiempo, al parecer, se han ido desentendiendo de su compromiso. De hecho, las reuniones mensuales que se hacían hace varios años, ya no se hacen y los socios ya no aportan las cuotas de cada mes con las cuales se sufragaba buena parte de los gastos de la fiesta y, el Hermano Mayor, ya no cumple a cabalidad "sus responsabilidades". Tal situación orilló a la familia que hospedaba a los santos a vender su camioneta para poder hacerse cargo de los gastos, que fueron de alrededor de $\$ 12000$ pesos.

En 2007, los anfitriones prepararon las siete ramadas, pero fueron ellos quienes tomaron la iniciativa -incluso las adornaron con panes, fruta y refrescos-, en vista de que ninguno de los Hermanos se ofreció a hacerlas (fotografía 3).

\footnotetext{
${ }^{16}$ Los jaraneros son los que ejecutan el baile regional de Yucatán, cuyas piezas musicales son llamadas “jarana”.
} 
Según nos explicaron, ese año la falta de interés fue mucho más allá: ni siquiera contaron con la asesoría del Hermano Mayor, "demasiado ocupado" para ayudarlos. Con la consiguiente molestia, la familia tuvo que buscar otra persona que los auxiliara.

A pesar de los tropiezos iniciales, las actividades continúan más tarde con el rezo de la novena y, cerca de la medianoche, con la llegada del grupo de jaraneros. En cuanto entran, los bailarines se dirigen hacia donde se encuentran las cruces, las saludan y se persignan, al salir, dan una vuelta nuevamente y saludan - ahora a los asistentes- enseguida da inicio la vaquería. A ritmo de $3 / 4$ y de $6 / 8$, los pasos de jarana van conquistando el ánimo de los presentes, que acaban por incorporarse animadamente al festejo, una vez concluida la ejecución de

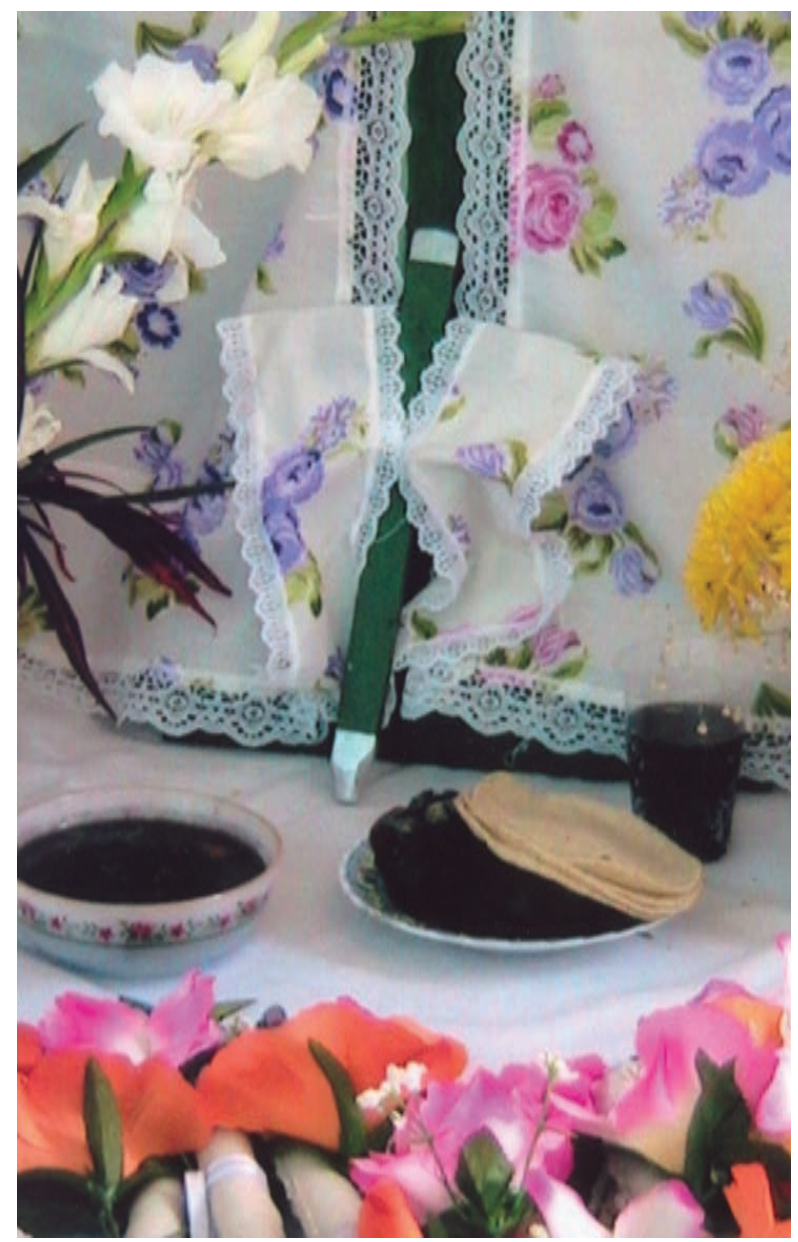

Fotografía 3. 
aquéllas, el conjunto musical interpreta una serie de piezas de cumbia, mambo, pasodoble y hasta música norteña. El baile termina a las 2.30 de la mañana.

La prolongada jornada del día anterior no impide que las actividades del 3 de mayo comiencen desde muy temprano. Desde las seis de la mañana, la familia responsable de las cruces - en especial las mujeres - se concentra en la tarea de preparar la comida ritual que se servirá a los Hermanos de las Siete Cruces.

Mientras tanto, aquellos que se ofrecieron a llevar una cabeza de cochino, se preparan cada uno para adornar la que van a entregar, una vez que han terminado de cocerla en un horno subterráneo. Para poder hacerlo, la colocan en un recipiente de plástico de considerable tamaño. Enseguida colocan en su hocico un pedazo de pan "francés" y, luego la cubren con algunos bejucos a modo de armadura. Sobre esta estructura colocan papeles de colores y banderitas (fotografía 4).

Una vez lista, cada Hermano llevará su ofrenda a la casa donde se encuentran las cruces, colocándola al pie de la cruz que él elija. Esto puede ocurrir en cualquier momento a lo largo del día, lo mismo que la visita de la gente del pueblo, que lleva velas y veladoras, ofrece algunos rezos y ejecutan el cambio de salud, es decir, devuelven dos muñecas por la que tomaron el año anterior o recogen una, como señal de su petición, prometiendo regresarla junto con otra la siguiente fiesta.

Por la tarde el Hermano Mayor y otros integrantes del grupo llegan a comer a la casa. Es entonces cuando se acuerda quién se llevará las cruces para custodiarlas el siguiente año. Algunos compran raciones de chilmole y con esto ayudan a quien pagó la fiesta. (Fotografía 5).

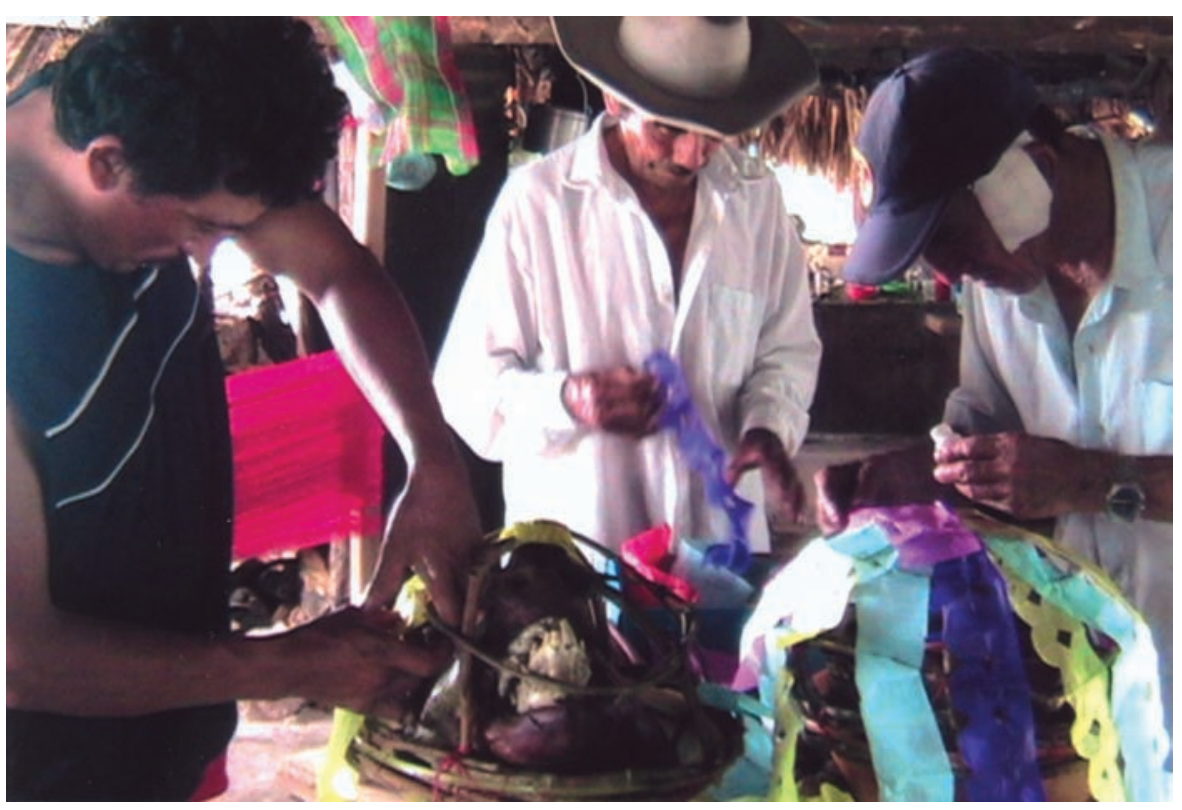

Fotografía 4. 


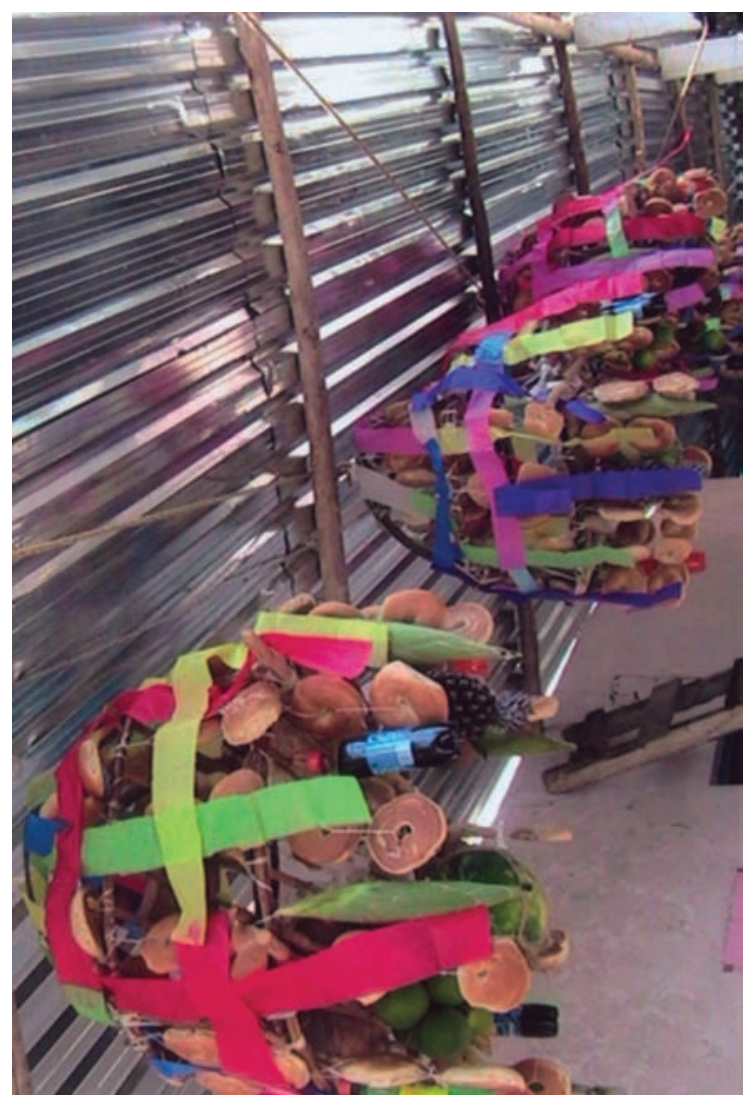

Fotografía 5.

A eso de las ocho de la noche, los bailarines llegan al lugar y con una vuelta a la pista de baile, marcan el inicio de la vaquería. Después de tres o cuatro piezas de música, los jaraneros ${ }^{17}$ ponen sobre sus cabezas las de cochino y ejecutan la tradicional danza que lleva este nombre. Luego devuelven las ofrendas a su lugar, para que los Hermanos las recojan y las lleven de regreso a sus casas. Este año la familia responsable de las cruces repartió el contenido de las ramadas entre los asistentes. El baile, con algún descanso de por medio, concluye a las 2.30 de la mañana.

Antes de amanecer, apenas una o dos horas después, la familia anfitriona baja las cruces del altar y se prepara para trasladarlas a la que será su nueva casa durante el siguiente año. Los músicos acompañan la procesión mientras cantan iViva Cristo Rey! y se revientan voladores. En este recorrido puede participar quien lo desee.

${ }^{17}$ Son 10 parejas de jaraneros. 
Al llegar a la nueva casa, los santos son colocados en un altar cubierto con manteles blancos (las mesas del altar y los manteles son propiedad de las cruces). Ahí se les ofrecen flores, velas y veladoras y se reza un rosario, al término del cual concluye oficialmente la celebración anual.

Es importante señalar que las actividades de 2006 y 2007 tuvieron diferencias importantes. Para la primera, el Hermano a cargo de las cruces construyó un tinglado ${ }^{18}$ de madera, con techo de palma y piso de tierra apisonada en la entrada de su casa, tres días antes de la fiesta. La construcción, de unos $3 \mathrm{~m}$ de largo por 3 de ancho, sirvió como pista de baile y como área de resguardo para los músicos durante los dos días de fiesta. Esta actividad —es decir, la construcción- involucró a los hombres de la familia, pues se trata de un trabajo que requiere habilidad y fuerza física. Mientras tanto, las mujeres limpiaban la casa y acomodaban las sillas para los rezos.

Poco después del mediodía, la señora de la casa sirvió la comida de los santos: siete platos de chicharra con sus respectivas tortillas y vasos de refresco. Un par de horas más tarde, los platos se retiraron y ella cambió la ropa a las cruces. La comida retirada del altar se guardó para la cena familiar.

Por la tarde, los músicos habían instalado su equipo y los hombres colocaron las sillas alrededor del tinglado. Los puestos de cerveza estaban listos frente a la casa y las visitas comenzaban a llegar ante las cruces y hasta la pista de baile. A eso de las siete y media, daba inicio el que sería el último rezo, con la mayor parte de los devotos fuera del reducido cuarto donde se encontraban las cruces. En tanto, las anfitrionas comenzaban a asar los chiles y preparar el recado con el que se haría el chilmole. Esa noche, la familia cenó chicharra, frijoles y refresco.

Más tarde, alrededor de la medianoche, el grupo de jaraneros - ocho parejas- arribó al lugar, ataviado con trajes típicos (terno de hilo contado, flores y moño en la cabeza, las mujeres; filipinas y pantalones blancos, alpargatas y paliacates blancos bordados, los hombres). La mayoría de la gente iba "muy bien vestida”, con vestidos, pantalones, faldas y blusas de vistosos colores, en su mayoría eran adolescentes y señoras, pero pocas mujeres jóvenes. Fueron muy pocas las señoras que llegaron de hipil.

Después de saludar a las cruces — primero las mujeres, luego los hombres-, los jaraneros esperaron afuera a que los músicos afinaran sus instrumentos. Tres piezas más tarde, el grupo comenzó por fin a bailar. Resulta un tanto curioso que, luego del trabajo que requirió su construcción, los bailarines no utilizaron la "pista" de tierra, sino la banqueta, pues explicaron que así "no se echan a perder los zapatos y podemos bailar mejor".

${ }^{18}$ En su libro Fiestas y gremios del oriente de Yucatán (1993:35-36) Quintal menciona una descripción de Stephens sobre la fiesta Ticul, se trata del baile de las mestizas y dice lo siguiente: "la enramada o salón de baile era un cobertizo como de ciento cincuenta pies de largo, rodeada de una balaustrada de ruda madera, cubierto de costales para proteger a los espectadores de la intemperie, e iluminada de luces colocadas en faroles. El piso era de mezcla compacta o endurecida". 
Los demás asistentes observaban el baile y sólo una pareja de ellos se animó a integrarse a la jarana. En tanto, los voladores seguían tronando y el consumo de cerveza continuaba. La vaquería terminó a las 2 de la mañana.

Pareciera que en el año 2006 la fiesta llegó a una severa crisis: ninguno de los Hermanos se ofreció a hacer las ramadas y sólo se reunieron seis cabezas de cochino, pues uno de ellos simplemente no cumplió con lo acordado, sin ofrecer ninguna explicación al respecto; además, a la hora de la comida, solamente llegaron cuatro hermanos a la casa donde estaban las cruces y ninguno colaboró comprando chilmole.

En esa reunión se dieron cuenta de que nadie se había ofrecido a recibir las cruces el próximo año (2007). Quien tenía las cruces comunicó a los Hermanos que no las podría tener otro año, pues la celebración de la fiesta le significó tal deuda que no sabía cuánto tiempo le llevaría saldarla. Los hermanos se retiraron de la casa sin haber llegado a un acuerdo.

Por fortuna, cerca de las 11 de la noche, una mujer y su esposo, quienes no pertenecen a la hermandad, llegaron para ofrecerse como anfitriones de las cruces, luego de haberse enterado de que no había a dónde llevarlas esa noche. Por primera vez en muchos años las cruces no estarían en manos de los Hermanos; sin embargo, al año siguiente la historia se repetiría, de manera que la fiesta del 2008 sería auspiciada por una familia que tampoco forma parte de aquel grupo.

Como ya se dijo, otro de los cambios más notorios fue que en 2007, la familia anfitriona decidió pedir permiso al presidente municipal para celebrar la vaquería en los bajos del Palacio Municipal, ${ }^{19}$ como estrategia para ahorrar una importante cantidad de dinero, de modo que por primera vez el baile no se efectuó en un domicilio particular.

La hechura de las ramadas, en esta ocasión, estuvo a cargo de la propia familia que resguardó las cruces ${ }^{20}$ en vista de que ninguno de los Hermanos se ofreció a hacerlas. Las siete estructuras — de medio metro de largo y $40 \mathrm{~cm}$ de ancho- se elaboraron con dos días de anticipación, de modo que el día 2 de mayo, poco antes del mediodía, la familia y algunos vecinos pudieron colgar los 300 panes en forma de dona — sin manteca, para reducir su fragilidad — que, junto con elotes y frutas como piña, naranja y mamey, y refrescos embotellados, integraron la ofrenda anual. Todas fueron semejantes, excepto la última, que fue más pequeña y sólo llevaba bizcochos, según nos explicaron porque así lo marca la tradición:

[...] la última ramada es de puro bizcocho, no se le pone frutas, ni panes [...] nada de eso $[\ldots]$ solo el bizcocho, y pues son de diferente su tamaño porque los santos

\footnotetext{
${ }^{19}$ En el oriente del Estado la vaquería de la fiesta patronal se lleva a cabo, casi siempre, en "los salones" (corredor) del Palacio Municipal. Véase Quintal Avilés, 1993.

${ }^{20}$ Este año, los santos se encontraban en una casa desocupada, propiedad del anfitrión. Como el lugar era pequeño, los trasladaron a la casa que el anfitrión habita junto con su familia. Ahí, las cruces quedaron hacia un costado de la vivienda, pues de esa forma quedaba un espacio más amplio para que los devotos pudieran sentarse cómodamente a rezar.
} 
no son todos iguales, esa ramada grande pues es para el santo más grande [...] ándale $[. .$.$] ese que está mero en el centro, así es la costumbre, cuando le hacen$ sus ramadas pues así de diferente tamaño se hace, le pones la fruta que tú quieras, y eso sí [...] lleva sus panes de esa forma como donas. Antiguamente [...] dicen que los antiguos hasta sus panales le ponían, ahora ya no, nadie lo hace.

Una vez adornados con papeles de colores, las ramadas se colgaron a modo de piñatas.

Ya con la ramada lista, las cruces reciben nuevamente ofrenda de comida y, poco después, sus esforzados devotos disfrutarían, como ellas, de un plato de chicharra. Durante la comida, los comentarios sobre la falta de compromiso de los Hermanos estuvieron a la orden del día. Después de comer, a eso de las 4:30 de la tarde, el anfitrión reventó siete voladores, en tanto que su mujer tocaba el tunkul, porque nos explicaba, "con esto los antiguos llamaban al rezo, así lo hacían antes del rezo, y como hoy es el último rezo pues hay que tocar el tunkul temprano para que la gente venga más tarde a rezar", si bien la realidad es que el sonido grave de este instrumento no se escuchaba más allá de la casa. Para este momento, junto al altar había un garrafón de agua purificada, la misma señora nos advirtió que era agua bendita y que se repartiría el último día de la fiesta a todo el que lo solicitara.

A las seis, mujeres, niños, jóvenes, hombres adultos y ancianos comenzaron a llegar con velas y veladoras que encendían a las cruces, en espera de que comenzara el rezo. Un par de horas y siete voladores después, la novena comenzó entre dudas de los más jóvenes ante las “cosas" que colgaban del techo —las ramadas-, porque tal parece que pocos integrantes de las nuevas generaciones conocen la historia de las cruces y su fiesta. A pesar de lo ocurrido con la organización, a la novena asistieron varios hermanos, entre ellos el Hermano Mayor y responsable principal de las Siete Cruces.

Mientras la rezadora hacía su labor, los niños tocaban el tunkul.

Al mismo tiempo, en el Ayuntamiento las sillas y los músicos estaban listos. Nuevamente, siete voladores marcaron el inicio de la vaquería, aunque no fue sino hasta las once de la noche que la gente comenzó a instalarse en el local. Este año sólo hubo un puesto de cerveza de la Superior, a diferencia de los tres del año pasado. Solamente cinco señoras portaron el tradicional terno, las asistentes fueron de pantalón de mezclilla o gabardina, minifalda y blusas o vestido. Los hombres llegaron también de mezclilla o bermuda y sólo los mayores llevaban —unos cuantos- sombrero y alpargatas.

Ante esta concurrencia hizo su entrada la embajadora, portando una enorme corona, junto con su séquito y, detrás, los niños jaraneros con su embajadora infantil. Bailaron cinco jaranas y la velada concluyó con "El Torito”21 y la vuelta a

\footnotetext{
${ }^{21}$ En esta jarana la mujer desempeña el papel de toro que embiste, se supone que sin dejar de bailar, contra el torero que es para el caso su pareja masculina de baile (Quintal, 1993: 23).
} 
la pista. Después la cumbia motivó a algunos de los escasos asistentes a sumarse a la fiesta.

El día 3 de mayo de 2006, las actividades también tuvieron algunas variaciones. Me referiré tan sólo a las más significativas, a fin de no perder el hilo conductor entre el mar de detalles.

La jornada comenzó muy temprano, con la limpieza del lugar y la preparación - cocción y adorno- de la cabeza de cochino. Las cruces fueron vestidas con "hipil" - hasta entonces llevaban ropa de tela floreada - y se les "dio de comer chilmole" (fotografía 6). Una hora después, cuando la comida ya estaba fría, se retiraron los platos porque, según me explicó la hija de la familia anfitriona, "los santos ya habían comido".

Así comenzó el desfile de los socios que llevaban ofrendas — cabezas de cochino- a la cruz de su preferencia. Nuevamente, el Hermano que había prometido participar, no llegó y uno de los santos se quedó sin obsequio. Este día la asistencia fue mayor, lo mismo que el número de voladores y la cantidad de cerveza consumida.

A las siete y media de la noche comenzó la vaquería. Mientras tanto, diez de los 80 Hermanos cenaban en el patio, discutiendo sobre el destino de las cruces para el año siguiente. Sin embargo, ninguno aceptó tenerlas, ante lo cual, una pareja de devotos ofreció recibirlas.

Sin mayores incidentes, después de la jarana comenzó el baile que terminaría cerca de las tres de la mañana. Hora en la cual las cruces fueron bajadas, se

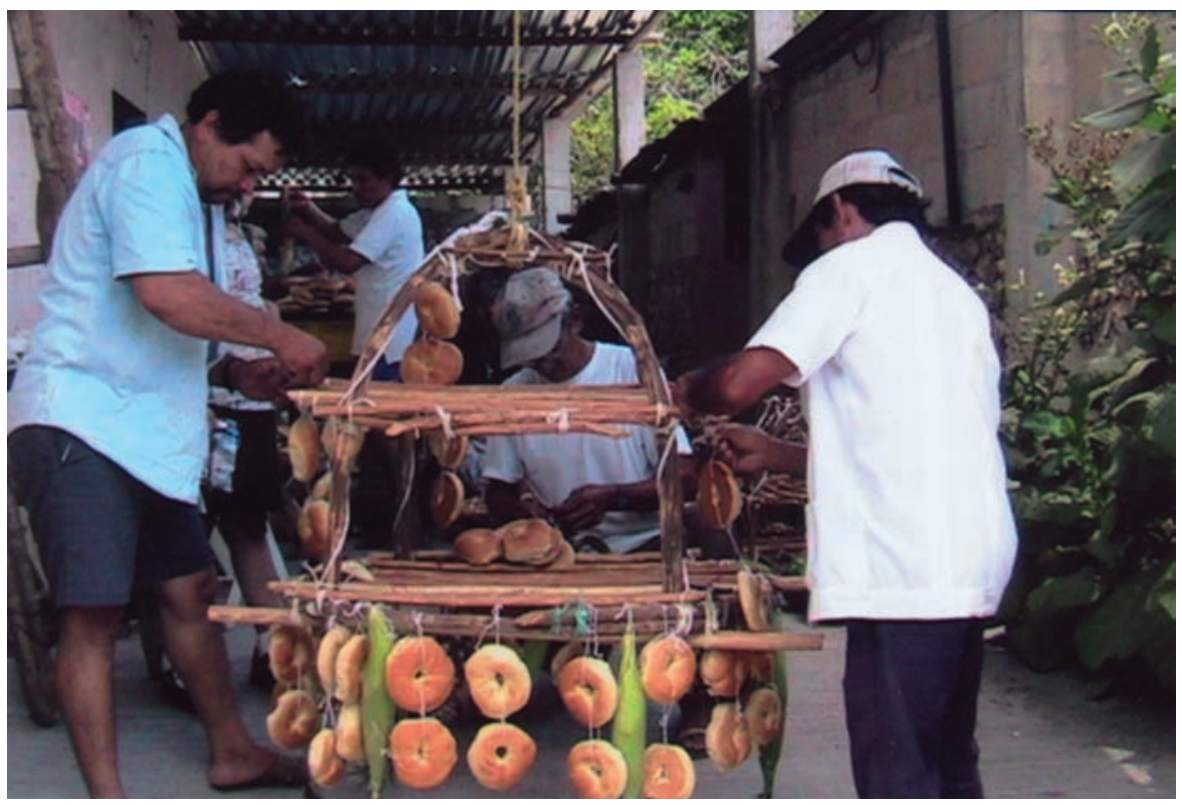

Fotografía 6. 
reunió manteles y floreros y se trasladó a las cruces a su nueva morada, apenas acompañadas por las siete personas que las llevaban y tres músicos. En la otra casa se les recibió con un rosario y así se dio por concluido el festejo.

Hemos hecho constante mención de la comida porque consideramos que es uno de los elementos más importantes de la fiesta. El chilmole se considera un platillo festivo tradicional maya. No en vano Negroe y Fernández (Op. cit.: 11) advierten que dentro de la fiesta puede señalarse una tendencia que relaciona la comida tradicional con aquellas que tienen un pasado y presente maya. La preparación de la comida, a cargo mayormente de las mujeres, crea las condiciones para que la lengua maya se manifieste como el canal de comunicación por excelencia para este grupo. Pero veamos qué ocurrió este año.

A diferencia de lo ocurrido en 2006, este año algunas señoras llegaron desde muy temprano con velas y veladoras porque "hoy es su día de los santos y tienen que tener sus velas encendidas todo el día”. Con todo, este año la comida — chilmole, con tortillas y refrescos- se les sirvió a las siete festejadas, pero sin rezo. Los traspiés también ocurrieron durante la preparación de las cabezas de cochino que cocinaron los anfitriones: se olvidaron de colocar una piedra en el hocico, para evitar que se cerrara, de modo que no hubo forma de introducir, más tarde, el consabido pan francés. Eso sí, las señoras prepararon las tradicionales sonajitas para las cabezas: "le buscas una jicarita y le pones sus maíces adentro y luego su trapo y lo amarras y ya estuvo [...] con eso llamas al cochino, porque el cochino come su maíz [...] pues lo mismo en el baile de la cabeza".

Hubo chilmole para la comunidad desde las cuatro de la tarde y jarana desde las seis, después de la cual comenzó el baile. En esta ocasión, a diferencia del año pasado cuando sólo observé un cambio de muñecas, pude ver al menos dos.

Nuevamente, los Hermanos llegaron a cenar pero no parecían apurados por decidir quién de ellos recibiría las cruces el próximo año, aunque se cuidaron de felicitar a los anfitriones por la organización de las fiestas. En cada mesa se colocó un plato para que la gente colaborara económicamente con lo que pudiera. No observamos que los Hermanos depositaran dinero. El que había llevado una cabeza de cochino, sí cuidó de llevársela de nuevo a casa. Más tarde se repartieron los panes y frutas de las ramadas, para seguir con la cena. A eso de la medianoche, la música comenzó nuevamente, pero la concurrencia era más bien escasa, los pocos que quedaban estaban borrachos o jugando en el parque, mientras que otros estaban con las cruces. Tal situación parecía anunciar el declive de la fiesta y la cercanía del fin de la misma.

A la hora de bajar las cruces, no quedaba ya ningún Hermano y, ante la falta de un nuevo interesado, las cruces serían recibidas, en la misma casa, por la mamá de la anfitriona de ese año. Así, se les recibió nuevamente con música, pan dulce y chocolate y con la esperanza de que "si Dios quiere el próximo año la fiesta va a ser más bonita porque ahora ya sabemos cómo se debe hacer". Enseguida apagaron las velas, las luces y se retiraron a descansar. 
Al día siguiente la familia llevó los floreros faltantes a la casa de las cruces. Se supone que ese día se les cambiaría de ropa, pero no ocurrió así. Con esto finalizó el festejo de las Siete Cruces del año 2007.

\section{Los cambios en la fiesta: reflexiones finales}

Existen en la antropología numerosos trabajos sobre el sistema de cargos, sobre organizaciones cívico-religiosas y el financiamiento de fiestas. Trabajos como los de Nash (1958), W. Smith (1981), Cancian (1976), Greenberg (1987), Chance y Taylor (1987), Korsbaek (1996), son un claro ejemplo de este tipo de estudios. Aunque no pretendo analizar cada uno de los trabajos, pues no es el objetivo de éste artículo, me parece importante mencionar que cada uno representó en su momento, la clave para entender y analizar los sistemas de cargos y fiestas de diferentes comunidades indígenas en México.

Topete Lara (2005) plantea que cuando nos aproximamos al estudio de las formas de organización social tradicional indígena, generalmente tropezamos con fiestas religiosas. Armados con una serie de teorías, modelos, tipologías y conceptos, casi de inmediato, los estudiosos del tema damos por supuesto que donde hay fiestas existe sistema de cargos. Éste es un grave error, la fiesta y el ceremonial religioso pueden efectuarse sin la experiencia del sistema de cargos porque el desarrollo de las mismas puede descansar en cualquier otra forma que revista la organización comunitaria para el ceremonial. También es posible que, aunque existe un sistema de cargos en una comunidad, cierta parte de las fiestas no descansa sobre su estructura y su funcionamiento (Lara, 2005: 96-97).

En los trabajos acerca del sistema de cargos es posible encontrar diferentes posiciones teóricas, y también variados énfasis temáticos dependiendo de las particularidades de la región de estudio. También es necesario aclarar que éste no forma parte de todas las instituciones culturales de los pueblos indígenas. Yucatán es un claro ejemplo de ésta situación.

Quintal (2003b) plantea que en la península de Yucatán las organizaciones religioso-ceremoniales de nivel comunitario, derivan de cuando menos tres instituciones: la cofradía, el sistema de guardias y el gremio. A partir de estos tres "modelos" las comunidades mayas han ido incorporando, reinterpretando y refuncionalizando elementos y aspectos que provienen de todas ellas. En las comunidades del Yucatán colonial, la cofradía no se desarrolló como en otras regiones de México. En manos de los mayas la cofradía y su empresa económica, la estancia ganadera, fueron la expresión por excelencia de la comunidad corporativa (Farriss en Quintal, 1991). Por su parte, el sistema de guardias, propio de los mayas macehuales de Quintana Roo, surge de la síntesis de dos instituciones, la cofradía y la "milicia yucateca". Finalmente, el gremio, que es una institución de culto religioso, aparece en el Yucatán "moderno" a fines del siglo xix y retoma también algunos elementos de la cofradía, pero en su versión urbana. Hoy su 
prestigio e influencia en las ciudades ha disminuido mucho, en las comunidades rurales, en su versión amayizada, adquiere cada día mayor influencia (Quintal, 2003b: 350-351). La estructura y organización de estas organizaciones religiosoceremoniales de nivel comunitario, como las llama Quintal, han sufrido cambios en su estructura y arreglo. Diferentes factores han contribuido a estructurar y organizar las fiestas de forma diferente. Las relaciones que establecen al interior de sus comunidades y al exterior de éstas permiten explicar, o al menos tratar de entender, la continuidad y cambios en estas fiestas comunitarias.

La fiesta de las Siete Cruces ha incorporado, refuncionalizado y perdido diversos elementos y aspectos a lo largo de casi 100 años. Ya en la primera parte del trabajo se describió de forma general la fiesta, y es en este espacio donde trataremos de responder las siguientes preguntas iporqué el antiguo modelo organizativo de financiamiento colectivo para la fiesta de las Siete Cruces se ha abandonado? Y ¿Por qué ese financiamiento se volvió individual?

Ya se explicó como se originó la Sociedad de Hermanos de las Siete Cruces, parece, por el nombre de la sociedad, una versión simplificada de la cofradía de acuerdo con los testimonios de diferentes personas de Tixméhuac. Esta sociedad tenía un dirigente, el Hermano Mayor, responsable de las reuniones y de administrar el dinero que se recaudaba del pago de cuotas de los socios. Durante un año uno de los socios se hacía responsable de las Siete Cruces, éste las tenía en su casa y era el encargado de festejarlas el dia 3 de mayo. Para esto recibía la ayuda económica del resto de los agremiados. Por otro lado, otros siete socios se apuntaban como responsables de construir una ramada y otros seis para cocinar una cabeza de cochino. Ésta es la forma en la que se organizaban para el festejo.

Durante varios años, a decir de los entrevistados, la fiesta se celebró siguiendo este esquema de ayuda. Con el paso del tiempo los cambios en la organización comenzaron a presentarse. De acuerdo con lo observado y con la información recopilada en campo, tenemos que el modelo original de financiamiento se abandonó por las siguientes razones: la primera es que, con el tiempo, algunos de los Hermanos fallecieron, otros dejaron de asistir a sus juntas mensuales, algunos más dejaron de colaborar pues la economía no marchaba bien, no siempre se lograban las cosechas y el costo de las cosas fue cada vez mayor: la Sociedad se debilitó.

Esta situación se reflejó directamente en el financiamiento de la fiesta y en la economía del Hermano a cargo de los festejos anuales, debiendo hacerse cargo de una enorme erogación, lo que provocó el desánimo y la deserción de varios integrantes de la asociación. Uno de los entrevistados señaló que durante los últimos cinco años, la fiesta

[...] ha ido de mal en peor, pues ya nadie quiere a los santos, ni los Hermanos las quieren porque ya no se ayudan entre ellos, entonces ¿qué ejemplo le dan a la demás gente del pueblo?, ya el Hermano Mayor no se ocupa de los santos, hace muchos años [...] como diez años [...] que ese hermano les hizo su fiesta porque él tenía los santos en su casa, pero ya nada. Antes hasta dos veces, hasta dos veces repetían su fiesta por el mismo hermano. Pues claro, si hay la ayuda pues claro que 
lo festejas así ¿verdad?, pero como le digo, hace como cinco años que ya está peor la fiesta, pues es que está muy caro, yo no soy hermano, pero mi tío sí era hermano, pero el ya se murió. Así cuando él tuvo a los santos en su casa los otros hermanos lo ayudaron. Bonita que estuvo la fiesta, yo estaba muchacho, tenía 18 años, ahora ya tengo 68 años y yo lo veo que la fiesta ya no es como antes.

Como hemos visto la crisis llegó a tal grado que, en 2006, ningún integrante del grupo se ofreció para recibir las cruces y, por primera vez en casi 100 años, los santos salieron del resguardo de los hermanos. La situación se agravó de tal modo que los anfitriones de 2006 se vieron amenazados por la posibilidad de tener que conservarlas bajo su cuidado hasta que —en opinión del Hermano Mayor - alguien más las solicitara. Ante tal panorama la familia aceptó, pero advirtió que para 2008 no haría fiesta pues el gasto es tal que resulta imposible realizarlo cada año.

Esto nos habla no sólo de la tensión que existe entre la Sociedad de Hermanos y la gente que recibe las cruces, y el abandono en el que aquella agrupación tiene a sus santos, sino también el por qué el financiamiento se volvió individual. No hay solicitudes para recibirlos por parte de sus integrantes, pues para llevar al cabo el festejo hace falta un enorme soporte económico que rebasa el núcleo familiar. No existen normas ritualizadas que guíen el trato entre quien entrega y quien recibe las cruces, como tampoco se ha establecido la retórica, la etiqueta y las formalidades apropiadas para cada fase de la fiesta. ${ }^{22}$ Los Hermanos no asisten a la fiesta, sólo el Hermano Mayor supervisa la entrega de las cabezas de cochino a los jaraneros para bailar y dar inicio a la vaquería y después se retira, tampoco están presentes en la entrega de las cruces y en el traslado a su nueva morada. Entonces, cada familia trata - a su entender- de cumplir con el compromiso, dentro de sus posibilidades, sin la vigilancia y orientación de quienes sí deberían saber. ${ }^{23}$

Junto con la cuestión económica existen otras razones por las cuales la fiesta se ha debilitado en los últimos cinco años, tal como la preferencia por otras fiestas — como la de Chumayel (pueblo vecino de Tixméhuac) de gran prestigio, o la

\footnotetext{
${ }^{22}$ En Popolá, localidad ubicada al oriente del estado de Yucatán, es el prioste (sería el Hermano Mayor en el caso de Tixméhuac) el encargado de llevar un registro de quienes se comprometen a participar en la fiesta del santo patrono. Son también responsables de entregar ofrendas, explicar la importancia del compromiso que se adquiere durante la celebración, preside e instruye acerca del protocolo y da fe del cambio de obligación o cuch de una familia a otra que se compromete en ese momento, y las ceremonias de cambio de prioste se llevan a cabo en algún lugar público de la comunidad (véase Quintal, 1997).

En Tixméhuac esto ya no sucede, parece ser que ya no existe ese compromiso entre los mismos Hermanos de la sociedad y las diferentes familias de la comunidad. Ya no se cumplen los deberes y tampoco se actualizan las obligaciones.

${ }^{23}$ Para más información sobre sistemas de normas, reciprocidad y conflictos en las fiestas patronales y los gremios véase el trabajo de Fernández y el de Quintal en el libro Aspectos de la Cultura Jurídica en Yucatán.
} 
que se le ofrece a la Cruz de Popox-, que incluso han propiciado que el Hermano Mayor optara por ser el responsable del cuidado de esta última, durante los nueve días que está en Tixméhuac. Su postura es muy clara y se hace evidente en su discurso: la importancia que le adjudica a la Cruz de Popox es innegable, tanto que evita hablar acerca de su responsabilidad como Hermano Mayor de las Siete Cruces. Las veces que intenté preguntarle sobre el festejo él decidió cambiar el tema de conversación, y se dedicó a hablar de su responsabilidad como socio de la organización de la Cruz de Popox.

Aunado a lo anterior, la edad de los socios de la agrupación es una condición clave. La mayoría tiene más de 70 años y no cuenta con ingresos suficientes para hacer frente a una responsabilidad de la magnitud de la fiesta.

Siendo realistas, debemos considerar que este panorama se perfila hacia la disolución de la hermandad y, probablemente, también de la fiesta. El paulatino envejecimiento, apatía y desgaste de la asociación supuestamente responsable, su anquilosamiento, la falta de promoción del culto a las cruces entre los jóvenes, han sido determinantes en el declive de los festejos en los últimos años. No parece haber, al menos en lo inmediato, ninguna reestructuración en la Hermandad, que permitiera retomar el antiguo vigor de la organización y que ayude a llevar la pesada y costosa carga de la fiesta anual de las Siete Cruces.

\section{Bibliografía}

Barabas, Alicia

1974 "Profetismo, milenarismo y mesianismo en las insurrecciones mayas de Yucatán”, International Congress of Americanists 41 (2): 609-622.

y Miguel Bartolomé

2003 "La ética del Don en Oaxaca: los sistemas indígenas de reciprocidad". En: La comunidad sin límites. La estructura social y comunitaria de los pueblos indígenas de México, Saúl Millán y Julieta Valle (coords.). México: INAH. Colección Etnografía de los pueblos indígenas de México. Tomo I, pp. 55.

Cancian, Frank

1976 Economía y prestigio en una comunidad maya. INI, México.

Chance, John y B. Taylor, William

1987 "Cofradías y Cargos: una perspectiva histórica de la jerarquía cívico-religiosa mesoamericana”, pp. 1-26. Antropología, boletín oficial del INAH, 14, Suplemento, México.

De León, Imelda (coord.)

1988 Calendario de fiestas populares (2a. ed.) México: Dirección General de Culturas Populares-SEP. 
Diccionario Maya Popular.

2004 Academia de la Lengua Maya de Yucatán. Mérida, Yucatán: Icy/Conaculta, INAH/SEP.

Fernández R., Francisco y Genny Negroe S.

1997 "Resistencia cultural a través de la religión popular. Los gremios y las fiestas de Yucatán”. En: Persistencia cultural entre los mayas frente al cambio y la modernidad, pp. 1-16, Arzápalo y Gubler (comp.). Mérida, Yucatán: Universidad Autónoma de Yucatán.

Fernández, Francisco.

1997 "La norma detrás de las fiestas patronales: prevención de conflictos en los gremios”. En: Aspectos de la Cultura Jurídica en Yucatán, Esteban Krotz (coord.). Mérida, Yucatán: Conaculta y Maldonado Editores, pp.177-207.

Girard, Rafael

1966 Los mayas eternos. México: Libro Mex Editores.

Greenberg, James B.

1987 Religión y economía de los chatitos. México: INI.

Korsbaek, Leif

1996 Introducción al sistema de cargos. Toluca: UAEM.

Nash, Manning

1958 "Political Relations in Guatemala", Social and Economics Studies, III: pp. 6575.

Pérez Sabido, Luis

1983 Bailes y danzas tradicionales de Yucatán. Mérida: Ediciones del DIF.

Quintal, Ella Fanny

1993 Fiestas y gremios en el oriente de Yucatán. Mérida: Gobierno del Estado de Yucatán, Cultur Servicios, CONACULTA, INAH. (Cuadernos de Cultura Yucateca, 4).

1997 "Sistemas de normas, reciprocidad, reproducción cultural: fiestas en el oriente de Yucatán”, pp: 161-175. Aspectos de la Cultura Jurídica en Yucatán, Esteban Krotz (Coord). Mérida, Yucatán: CONACULTA y Maldonado Editores.

2000 "Según su fe de cada uno: Patronos poderosos y control cultural en el oriente de Yucatán”, Religión popular: de la reconstrucción histórica al análisis antropológico (aproximaciones casuísticas), pp. 229-258 Negroe Sierra, Genny y Francisco Fernández Repetto (editores), Universidad Autónoma de Yucatán.

et al.

2003a "Ú lu’umil maaya wíiniko ob: la tierra de los mayas", Diálogos con el territorio. Simbolizaciones sobre espacio en las culturas indígenas de México. Alicia Barabas (coord.). México: INAH. Colección Etnografía de los pueblos indígenas de México. Tomo 1, pp. 273-359.

2003b "Solares, rumbos y pueblos: organización social de los mayas peninsulares". 
En: La comunidad sin límites. La estructura social y comunitaria de los pueblos indígenas de México, Saúl Millán y Julieta Valle (coords.). México: InAH. Colección Etnografía de los pueblos indígenas de México. Tomo I, pp. 291- 399.

Rejón Patrón, Lourdes

"Las cruces que sangran”, I'INAJ Semilla de Maíz. Revista de divulgación del patrimonio cultural de Yucatán 12, junio de 2001. Mérida: Conaculta/INAH.

Secretaría de Agricultura, Ganadería y Pesca

2005 Diagnóstico Municipal de Desarrollo Rural Sustentable del Municipio de Tixméhuac. Programa de fortalecimiento municipal. Mérida: Gobierno del Estado de Yucatán, Sagarpa.

Smith, Waldemar R.

1981 El sistema de fiestas y el cambio económico. México: FCE.

Topete Lara, Hilario

2005 "Variaciones del sistema de cargos y la organización comunitaria para el ceremonial en la región etnopurépecha”, Cuicuilco, mayo-agosto, 12 (034), pp. 95-129. México: Escuela Nacional de Antropología e Historia.

Tozzer, Alfred

1907 A Comparative Study of the Mayas and Lacandones. Nueva York: Archeological Institute of America.

XII Censo General de Población y Vivienda 2000 México: INEGI.

II Conteo de Población y Vivienda

2005 México: INEGI. 
